\title{
Access to Micro Credit by Women Entrepreneurs in Ghana: Sinapi aba Trust- Kumasi in Retrospect
}

\author{
Appiah Kusi, Suleman Yussif, Alhassan Ismail
}

To Link this Article: http://dx.doi.org/10.6007/IJARBSS/v9-i9/6336

DOI: $10.6007 /$ IJARBSS/v9-i9/6336

Received: 14 June 2019, Revised: 19 July 2019, Accepted: 30 August 2019

Published Online: 09 September 2019

In-Text Citation: (Kusi, Yussif, \& Ismail, 2019)

To Cite this Article: Kusi, A., Yussif, S., \& Ismail, A. (2019). Access to Micro Credit by Women Entrepreneurs in Ghana: Sinapi aba Trust- Kumasi in Retrospect. International Journal of Academic Research in Business and Social Sciences, 9(9), 590-613.

\section{Copyright: (c) 2019 The Author(s)}

Published by Human Resource Management Academic Research Society (www.hrmars.com)

This article is published under the Creative Commons Attribution (CC BY 4.0) license. Anyone may reproduce, distribute, translate and create derivative works of this article (for both commercial and non-commercial purposes), subject to full attribution to the original publication and authors. The full terms of this license may be seen at: http://creativecommons.org/licences/by/4.0/legalcode

\section{Vol. 9, No. 9, 2019, Pg. 590 - 613}

Full Terms \& Conditions of access and use can be found at http://hrmars.com/index.php/pages/detail/publication-ethics 


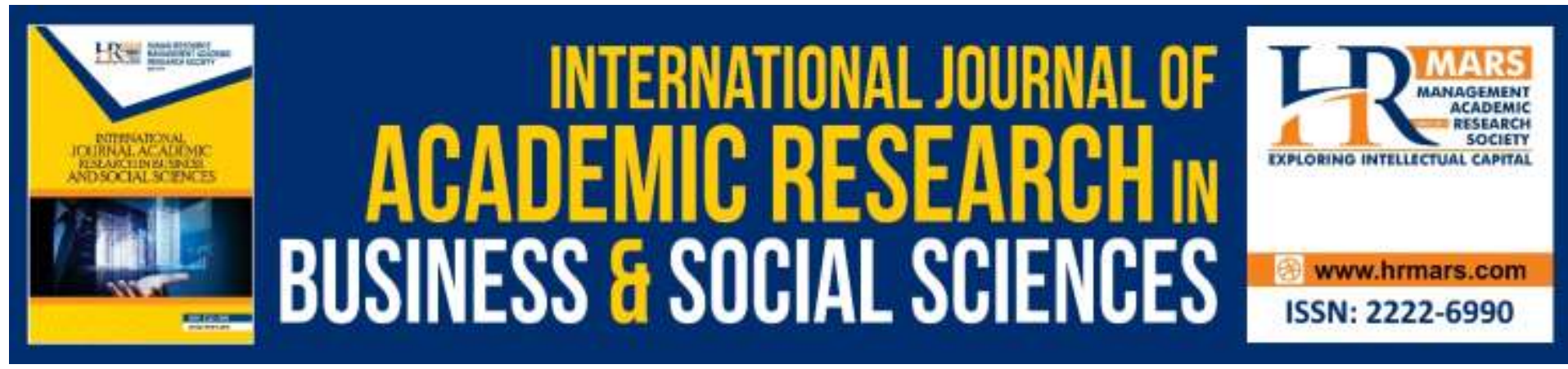

\title{
Access to Micro Credit by Women Entrepreneurs in Ghana: Sinapi aba Trust- Kumasi in Retrospect
}

\author{
Appiah Kusi, Suleman Yussif, and Alhassan Ismail \\ Lecturer, Wa Polytechnic, Wa, Ghana, Assistant Registrar, Wa Polytechnic, Wa, Ghana
}

\begin{abstract}
A developing country like Ghana should harness all its human and material resources for her socio-economic and enterprise development. It is imperative that in an economy like Ghana where savings are low and hence capital accumulation is very minimal, micro credit support for entrepreneurs in general and women in particular as pontificated by this study is critical. This is because women form the majority of the population of Ghana who also lack access to education, and formal credit and being treated as second fiddle to men in the socio-economic, religious and cultural set up. The techniques and methodologies used to collect the data for the research study included personal interviews, questionnaire, field survey and analysis of some official documents and brochures.

Studies have shown that micro credit support to women help to reduce the poverty level of the majority of the population. Asmah (2001) said "the basic cause of the problem facing women is poverty". She further stated that "statistics show that "women control about $62 \%$ of Ghanaian household resources and it is only fair that women are economically empowered for the benefit of the family and the country as a whole".

The research studied the Sinapi Aba Trust Micro Credit that indicated that a greater part of its credit was geared towards women entrepreneurs especially the urban poor with technical and managerial support to enhance the development and growth of their economic activities. The study revealed that the major set-back in Micro Credit is the high interest rate due to high overhead cost of Micro Credit hence the group credit scheme was most appropriate.
\end{abstract}

Keywords: Government Interventions, Microcredit, Impacted Positively, Women Entrepreneurs

\section{Background of the Study}

The issue of accessing micro credit to small scale and micro businesses especially for women has engaged the attention of governments, financial institutions and Non-Governmental Organizations for quite some time now in Ghana and other developing economies.

The traditional source of credit has been the commercial, development and rural banks and other financial institution. In recent times and about a decade ago emphasis have been placed on special micro credit finance to women entrepreneurs initiate by government, nongovernmental organizations and women oriented organizations as stated earlier.

In Ghana, the government's particular concern for the development of micro finance (credit) led to the enactment of National Board for Small Scale Industries NBSSI, Act 1981, Act 434 
and its subsequent launching of the Entrepreneurial Development programme in 1987 with the objective of equipping small and micro enterprise with management for increased efficiency. Subsequently the Business Advisory Centres were also established by the NDC government with an initial revolving fund of ten billion cedis and currently increased to hundred billion cedis.

In 2001, the government established Women Development Fund with initial seed money of twenty one billion cedis (C21 billion) (Asmah, 2001) to support women in micro and smallscale economic ventures.

The Micro Credit Enterprise Development of Christian Children's fund of Canada International Development Agency disbursed two hundred and thirty-one million and five hundred thousand cedis (231.5 million) to women groups in fifteen (15) communities of about 623 women through a local affiliate organization TumaKavi Development Association in the Savelugu-Nanton District. Adane \& Nyeko (2002).

A study shows that the small enterprise development projects supported by the World Bank totaling US\$ 3 million into projects to help small and medium enterprises in 36 developing countries, between $1973-1988$ revealed that, less than $10 \%$ of this sum actually reached the very smallest of the small scale enterprises (Levitsky, 2000).

This study therefore seeks to establish whether micro credit support by SINAPI ABA TRUST has impacted on Micro and small enterprises of women and what can be done to improve upon it.

\section{Theoretical Issues}

ISSER (1995) in the state of the Economy of Ghana of 1995 states " in adequate credit support from the banking system continues to impede the development of the private sector in the country." Small and medium sized enterprises are particularly vulnerable, since they have considerable difficulty competing against large companies and multinationals for bank credit. This study further stated "it is currently the policy of Bank of Ghana to promote as much as possible the development of non-banking institution as they are regarded as the most effective means to reach small business and the informal sector" (ISSER, 1995).

"As many as seven non-banking financial institution were licensed by Bank of Ghana in 1995. This brought the total number of registered non-banking financial institution operating in the country to twenty-three among which were 4 savings and loans companies (micro financing institutions).

Osei (1997) speaking on the topic "Rural Banks should support Women" implored rural banks in the country to institute programs that will address the credit needs of women". He asserted that it is fact that women are industrious and that whatever amount of money given them could be handled for the benefit of the society".

In addition Oduro (1998) speaking on the theme "African Women in National Development; challenges and prospects said that the attitude of many banks in the country is that they prefer given loans to men than women, even though women, when given the loans tend to pay promptly than men". 
Woode (2001) called for the acceleration of development initiative for women to contribute effectively towards economic growth in the country". Koeholoer (2002) IMF Managing Director in a five African nation tour said "he will be raising the issue of what is called microfinance with the World Bank president. Koehler has been banging the drum for small-scale credit on a number of occasions during his African tour".

Carr in Ocansey (1007) said "as knowledge of the small-scale sector has increased, it has become apparent that women play a major role in it, not just as employees and self-employed part-time workers but also as entrepreneurs."

"The problem of access to resource is seen as serious constraint for women entrepreneurs in most of the SADCC countries. Credit is a major problem, women usually lack the savings needed to put down the equity payment required to get a loan car in Ocansey (1997).

The constraints reviewed above suggest that in practice additional measures aimed specifically at women will be needed if women are to benefit to the extent as men.

\section{Exploring Non-Bank Financial Institution (NBFI) Regulation}

Non-Bank Financial Institutions refers to non-bank institutions and non-bank financial services providers (NBFI act 774, 2008). Non-banking Financial Institutions carry out financing activities but their resources are not directly obtained from the savers as debt. Any institution which is not a bank as defined by legislation but is involved in finance (Lemuel, 2009). NBFI's are formed for various reasons such as the offering of financial services that are not appropriate for banks because of the nature of their risks, operating as niche providers, capitalizing on the benefits of specialization, etc (Ofoeda, Abor and Adjasi, 2012). The activities of NBFls serve to enhance competition and increase the depth of the financial market. By reducing concentration and providing alternative sources of finance (Ofoeda, Abor and Adjasi, 2012). Some of the functions of Non-Bank financial operators include: leasing operations, money lending operations, money transfer services, mortgage finance operations, non-deposit-taking micro finance services, credit union operations, and any other services or operations as the Bank of Ghana may from time to time by notice designate as such (BOG, 2013). Some examples of NBFI's are: Bayport Financial Services Ltd (A finance house); Multi Credit Savings \& Loans Co Ltd (A Savings and Loans Company); Ghana Leasing Co Ltd (A Leasing Firm); Dalex Finance and Leasing Company Ltd (A Finance and Leasing Firm); and Ghana Home Loans (A mortgage finance firm). Before a Non-Bank Financial Institution engage in any form of activity or business in Ghana, the institution has to be licensed. Some of the requirements that a Non-Bank Financial Institution has to fulfill before it can be given the go ahead to operate are stipulated below:

i) It must be a body incorporated in Ghana under sections 8 and 9 of the companies Act 1963 (Act 179) with the sole authorized business of carrying on of a non-bank financial services

ii) Is in the case of a credit union registered and incorporated under section 5 and 6 of the cooperative societies Act, 1968 (NLCD 252) and has satisfied the minimum capital requirement determined in accordance with section 12 of this Act.

Differences among countries in the regulatory treatment of permissible activities for banks and the formation of financial conglomerates are wide, but all countries share the ultimate 
regulatory and supervisory goal of promoting systemic stability (Haubrich and Santos, 2003; Barth et al., 2008). Additionally, regulation and supervision may also be aimed at promoting the development and efficiency of the banking sector. The important issue is what mix of permissible activities and degree of financial conglomeration is best for banks in each country around the world to achieve these goals. According to (Stiglitz,2001), all arguments that support the application of regulation to banks are naturally extended to non-bank financial institutions. He further explains 'the extent and nature of the regulation may differ markedly between banks and non-banks depending on the role the latter institutions play in the economy.

\section{The Concept of Microfinance and Microcredit}

The term 'microcredit' was first coined in the 1970s to indicate the provision of loans to the poor to establish income-generating projects, while the term 'microfinance' has come to be used since the late 1990s to indicate the so-called second revolution in credit theory and policy that are customer-centred rather than product-centred (Elahi and Rahman, 2006). But the terms 'microcredit' and 'microfinance' tend to be used interchangeably to indicate the range of financial services offered specifically to poor, low-income households and microenterprises (Brau and Woller, 2004). Microfinance principally encompasses microcredit, micro-savings, micro-insurance and money transfers for the poor. Microcredit, which is part of microfinance, is the practice of delivering small, collateral-free loans to usually unsalaried borrowers or members of cooperatives who otherwise cannot get access to credit (Hossain, 2002) Micro-finance as posited by the United Nations (2005) is defined as the provision of financial services and the management of small amounts of money through a range of products that are targeted at the poor people. This product includes loans, savings, insurance etc. Contributing to the conceptual explanation of micro finance, Almeyda and Branch (1999) defined it as 'the provision of credit, savings, and other financial services to lower-income groups'.

\section{Challenges in Microfinance Operations}

The microfinance system can be separated into three distinct but integrated levels of activity: micro, meso and macro. The micro level involves both microfinance clients and microfinance service providers. From the borrowers' perspective, challenges often relate to their limited financial sophistication, which can increase their vulnerability to predatory lending practices. From the lenders' perspective, a lack of sustainable funds and limited managerial experience present operational challenges. The meso level includes "support services and infrastructure" (e.g., microfinance associations, credit bureaus, auditors, etc.). Limited capacity, including an inadequate supply of technical service and education providers, presents a challenge at the meso level. The macro level is comprised of central banks, ministries of finance and other national government entities. At this level, systemic failure or a contagious collapse of MFIs, exposed to the same underlying risks is a key challenge for policy makers (Ali et al., 2009). At the borrowers' level, Kazmin (2010) argued that the small amount that is being disbursed by the microfinance institutions has led to the practice of multiple borrowing. The high interest rates and the use of coercive collection tactics forced some borrowers to commit suicides. This is also the period when a lot of microloan repayment crises were reported in Morocco, Bosnia, Nicaragua and Pakistan (Kazmin, 2010). Morduch (1999) shifted the debate to the challenges of sustaining the microfinance sector as a result of increasing competition and the 
likelihood of over indebtedness on the part of borrowers. Lan and Tran (2005) aptly illustrated evidence of deficit in capacity of the microfinance organizations (MFOs) which affect their ability to access sufficient funding for their operations.

\section{Approaches of Microfinance}

There are two main diverse approaches of microfinance in the literature. These are the welfarist approach, also called the direct credit approach, and the institutionalist approach also called financial market approach (Morduch, 1999).

\section{Welfarist Approach}

The welfarist approach focuses on the demand side, which is to say on the clients. This approach support the idea of subsidizing microcredit programs in order to lower the cost for the microfinance institutions so they can offer low interest rates on their loans (Morduch, 1999). The performance of the MFI's are measured through household studies with focus on the living standard of the individuals; number of saving accounts, number of loans, productivity improvement, incomes, capital accumulation, social services such as education and health as well as food expenditures (Congo, 2002).

Welfarist argues that MFIs can achieve sustainability without the institutionalist definition of self-sufficiency (Woller et al., 1999). They further argue that gifts, for instance subsidies, from donors serve as a form of equity, and as such the donors can be viewed as investors. Unlike investors who purchase equity in a publicly traded firm, MFI donors do not expect to earn monetary returns. Instead, these donor-investors realize an intrinsic return. These donors can be compared to equity investors who invest in socially responsible funds, even if the expected risk-adjusted return of the socially responsible fund is below that of an index fund. These socially responsible fund investors are willing to accept a lower expected return because they also receive the intrinsic return of not investing in firms that they find offensive.

\section{Institutionalist Approach}

The institutionalist view of microfinance argues that an MFI should be able to cover its costs with its revenues. Institutionalists feel self-sufficiency leads to long-term sustainability for MFIs, which will facilitate greater poverty alleviation in the long-term. The institutionalist argument is consistent with Congo (2002) who discusses historical cases in an attempt to identify the institutional designs that facilitated success and sustainability for 19th century loan funds in the UK, Germany, and Italy.

Secondly, the institutionalist approach criticizes subsidization because it leads to high, unpaid rates and transaction costs, which have led to the failure of many microcredit programmes. They mean that it is not sustainable for the MFls to be subsidized and that the subsidies lead to an inefficient allocation of the financial resources. The economists supporting this view mean that the welfarists make the wrong assumptions when they say that the repayment of interest rate must be low, because the clients are not creditworthy and unable to save and that commercial banks could not survive in rural areas because of the high costs of offering financial services to poor households. 


\section{Models of Microfinance Interventions}

MFIs employ wide variety of implementation methods to reach their clients. These methods are called models of MFI. The Grameen Bank has identified fourteen different microfinance models of which the research focused on three in the literature. They are; Rotating Savings and Credit Association (ROSCAs), the Grameen Bank and the Village Banking models, as these are the three microfinance models that are mostly practiced in Ghana.

\section{Rotating Savings and Credit Associations}

These are formed when a group of people come together to make regular cyclical contributions to a common fund, which is then given as a lump sum to one member of the group in each cycle (Grameen Bank, 2000). According to Harper (2002), this model is a very common form of savings and credit. He states that the members of the group are usually neighbours and friends, and the group provides an opportunity for social interaction and is very popular with women. They are also called merry-go-rounds or Self-Help Groups (Yunus, 1999).

\section{The Grameen Solidarity Group Model}

This model is based on group peer pressure whereby loans are made to individuals in groups of four to seven (Yunus, 1999). Group members collectively guarantee loan repayment, and access to subsequent loans is dependent on successful repayment by all group members. Payments are usually made weekly (Ledgerwood, 1999). According to Berenbach and Guzman (1994), solidarity groups have proved effective in deterring defaults as evidenced by loan repayment rates attained by organizations such as the Grameen Bank, who use this type of microfinance model. They also highlight the fact that this model has contributed to broader social benefits because of the mutual trust arrangement at the heart of the group guarantee system. The group itself often becomes the building block to a broader social network (Yunus, 1999).

\section{Village Banking Model}

Village banks are community-managed credit and savings associations established by NGOs to provide access to financial services, build community self-help groups, and help members accumulate savings (Hulme, 1999). They have been in existence since the mid-1980s. They usually have 25 to 50 members who are low-income individuals seeking to improve their lives through self-employment activities. These members run the bank, elect their own officers, establish their own by-laws, distribute loans to individuals and collect payments and services (Grameen Bank, 2000). The loans are backed by moral collateral thus the promise that the group stands behind each loan (Global Development Research Centre, 2005).

\section{Microfinance and Poverty Reduction}

While Hulme (1997) indicated that research up to the 1990s tended to focus on how to improve the microfinance industry, rather than on how to prove impact, studies about and questions regarding the impact of microfinance are not new (Goldberg, 2005; Hulme and Mosley; 1996, Rogaly, 1996). Some within the microfinance industry argue that the market is an adequate proxy for impact, i.e. client retention and high repayment rates show that poor people are happy with microfinance (Wrenn, 2005), and that accumulating all the anecdotal stories of the positive impact of microfinance is sufficient. Academic studies though have 
found mixed impacts, ranging from positive impacts on household income and consumption, to modest or no impact, to negative impacts. Microfinance is universally acknowledged to be one of the most effective and sustainable strategies for poverty reduction by way of bringing financial services to the grassroots communities at close proximity. The fundamental argument for micro-credit and micro-savings, as opined by Stewart et al (2010) stem from the fact that they allow the poor to invest their money in the future, increase their incomes and lift themselves out of poverty. Changes in income levels of both individuals and households are severally used as a measure of the impact of microfinance on poverty reduction (Johnson and Rogaly, quoted in Makina and Malobola, 2004). Microfinance has received extra attention lately, since UN declared 2005 to be the International Year of Microcredit. This correlates well with the Millennium Development Goals, where one of the goals is to decrease by $50 \%$ the proportion of people living in extreme poverty by 2015 (Lindvert, 2006). One of the first field experiments about the impact of micro-savings - through a commitment savings account was undertaken by Dupas and Robinson (2009) in rural Kenya, where they found a positive impact on business investment and household expenditure and income. Microfinance has proven to be an effective and powerful tool for poverty reduction. Like many other development tools, however, it has insufficiently penetrated the poorer strata of society. The poorest form the vast majority of those without access to primary health care and basic education; similarly, they are the majority of those without access to microfinance. While there is no question that the poorest can benefit from primary health care and from basic education, it is not as intuitive that they can also benefit from microfinance, or that microfinance is an appropriate tool by which to reach the Millennium goals (Morduch and Haley, 2002).This 'microfinance-poverty reduction' debate influenced the Government of Ghana to implement Ghana's Growth and Poverty Reduction Strategy (GPRS) which has microfinance as one of its poverty reduction tools (Ministry of Finance and Economic planning, 2003). Literature search revealed that households income is higher with families who have access to credit as compared to non-borrowers (Remenyi and Quinones, 2000) and the poor are more disciplined borrowers and savers, capable of repaying on time and to save (UNICEF, 1997).

At the core of any poverty reduction programme is the implementation of microfinance scheme. This fact was acknowledged by Otero (1999) when he argued that microcredit creates access to productive capital for the poor, which together with human capital, addressed through education and training, and social capital, achieved through local organization building, enables people to move out of poverty. It was added that, by providing material capital to a poor person, his or her sense of dignity is strengthened and this can help to empower the person to participate in the economy and society (Otero, 1999).But Wright (1999) has offered a counter view that income levels cannot be the only measure: increasing income does not per se mean that poverty is reduced, as it depends on what the income is used for. And more recently, the poor are diverse vulnerable households with complex livelihoods (Matin et al., 1999). The outcomes used to measure the impact of microfinance on the poor also then have to take into account these changed conceptualisations of poverty and who the poor are. 


\section{Microfinance and Access to Credit}

Lan \& Tran's study in Viet Nam identified Microfinance Organization (MFOs) as critical sources of borrowing by clients. Lan \& Tran (2005) argued in favour of MFOs that, they enhance access to credit through clients borrowing to as high as $43 \%$ of all borrowing. This was greatly attributed to meeting the financial service needs of the poor and clients-centred approach that is being used.Access to microfinance is credited with reaching the poorest, increasing their income, galvanizing them into collective action to resist oppression, with empowering repressed poor people so that they are able to take control of their lives, with enabling families access to better health care, education and nutrition; and with providing a costeffective, sustainable development model that is applicable not just in developing countries but also among poor communities in the developed world (Wright, 2000).In addition to these social and development arguments for microfinance, there is an economic case that leads us to expect that improved financial access through microfinance will lead to increase incomes as poor people work themselves out of poverty, and furthermore that targeting women may have the greatest impacts. As Armendariz and Morduch (2010) explain, provision of credit in capital-poor, credit-constrained economies should provide relatively high returns on investment compared to capital-rich economies where opportunities are already maximised. Furthermore, by reducing credit constraints and providing financial services in environments where credit is hardest to access, and to groups such as women who are most-commonly excluded from the formal market, the potential for profits is even higher (Mel et al., 2009).

\section{Empowering the Poor through Microcredit}

Since the 1970s microfinance has come to be seen as an important development policy and a poverty reduction tool for men as well as women and by 2010 over 200 million people were served by thousands of microfinance institutions (MFIs) (Maes and Reed 2012). Microfinance now includes a suite of financial tools which aim to provide banking services to the 'unbanked' through the provision of small cash loans (micro-credit), the lending of productive assets (micro-leasing), facilities to save (micro-savings), and most recently insurance policies (microinsurance) and money transfers. These instruments are seen as reducing and mitigating risks and vulnerabilities experienced by poor people (Hulme et al. 2009). Some even argue (Littlefield et al., 2003; Simanowitz and Brody, 2004) that microfinance is a key tool to achieve the Millennium Development Goals (MDGs). There is an assumption that extending access to financial services through microfinance will increase wealth and reduce poverty (Grameen, 2009, Khandker, 2005). Kofi Annan, then the United Nations Secretary General, described micro-credit in 2005 as 'a critical antipoverty tool - a wise investment in human capital. When the poorest, especially women, receive credit, they become economic actors with power. Power to improve not only their own lives but, in a widening circle of impact, the lives of their families, their communities, and their nation' (UNCDF 2005). Empowerment is said to be an important aspect of micro-credit schemes. Kabeer (1999) states that empowerment refers to the 'process by which those who have been denied the ability to make strategic life choices acquire such ability'; where strategic choices are 'critical for people to live the lives they want such as choice of livelihood'. Therefore micro-credit schemes cannot empower people directly but can help them through training and awareness creation to critique the existing norms, cultures and values which place them at a disadvantage position, and to help them have greater control over resources and their lives. Oakley (2001) identifies five key uses of the term empowerment in development studies, from which empowerment through 
economic improvement and empowerment of the individual are examples. Empowerment through economic improvement is an approach which has been extensively used with poor people. Based on the assumption that, poor people's relative powerlessness is primarily a function of their poverty, therefore interventions such as microfinance and small business activities, targeted at poor people, they will become agents of change in their community. Microcredit creates access to productive capital for the poor, which together with human capital, addressed through education and training, and social capital, achieved through local organization building, enables people to move out of poverty. By providing material capital to a poor person, his or her sense of dignity is strengthened and this can help to empower the person to participate in the economy and society (Otero, 1999). The aim of microfinance is not just about providing capital to the poor to combat poverty on individual level; it also has a role at an institutional level. It seeks to create institutions that deliver financial services to the poor, who are continuously ignored by the formal banking sector (Otero, 1999).

\section{The Concept of Small and Medium Enterprises (SMEs)}

Storey (1994, cited in Kayanula and Quartey, 2000) argues that there is no universally accepted definition for the term small and medium scale enterprises (SMEs). Definitions that emphasise the size of firms (number of employees, turnover, profitability, etc.) when applied to a sector could lead to all firms being classified as small, while the same size criterion when applied to a different sector could lead to a different result (Abor and Adjasi, 2007 cited in Kufour, 2008). Thus, firms differ in their levels of capitalisation, sales and employment. This has challenged any attempts at deriving a uniform definition. Despite this challenge, attempts have been made to distinguish between small and medium scale enterprises. Kayanula and Quartey (2000) reveal that the first attempt to overcome the definition challenge was by the Bolton Committee in 1971. The Bolton Committee used different criteria (number of employees, assets and turnover) to classify enterprises. Under the manufacturing, construction and mining \& quarrying sub-sectors, the number of employees is used as the indicator for distinguishing small scale enterprise from medium scale and large scale enterprises. Manufacturing, construction and mining \& quarrying firms are considered small if they employ less than 200 workers, 25 workers and 25 workers respectively.

In using a firm's turnover as another distinguishing feature, the Committee points out that a turnover of 50,000 pounds or less is used to classify retailing firms, miscellaneous firms and service firms as small. Additionally, a turnover of 100,000 pounds or less is used to classify motor firms and wholesale firms as small. Thus, whilst a turnover of 50,000 pounds or less is used to classify retailing firms, miscellaneous firms and service firms as small, turnover of 100,000 pounds or less is used to classify motor trades and wholesale trades as small.In the case of road transport firms, the number of vehicles owned by the firm is used as the index for the classification. A road transport firm is classified as small if it owns five vehicles or less. In terms of ownership of SMEs, the Bolton Committee argues that there is a difficulty distinguishing between ownership and control. Thus, owners of SMEs play dual function (controllers and owners). From the above, the study notes that different criteria are used for classifying firms into different scales. Kayanula and Quartey (2000) criticise the Bolton Committee's definitions for using three different upper limits of turnover for the different sectors and two different upper limits of employees. They assert that the definition is complex and do not allow for cross-country comparison. Additionally, the use of monetary units as a basis for comparison is problematic. Using monetary units requires frequent updating to take 
account of general price changes. Due to the difficulty in defining SMEs especially having a definition that applies to all countries, Storey (1994 cited in Kufour, 2008) argue that there is a wide range of measurements for SMEs that vary from country to country. Premising upon the differences that exist among countries' definition of SMEs, the study considers definitions from official sources in Ghana as most relevant. The most commonly used criterion in Ghana is the number of employees (Kayanula and Quartey, 2000). The Ghana Statistical Service (GSS) considers firms with less than 10 employees as small scale and those with more than 10 employees as medium and large-sized enterprises. Thus, the GSS uses the 'employees criterion' used by the Bolton Committee to define small scale enterprise. Ironically, the GSS in its national accounts considers companies with 9 employees as medium scale enterprises. These inconsistencies in the employees cut off point breed confusion.

\section{Research Approach}

This study is a descriptive survey, which according to Babbie (1990) and Gay (1992), is useful for investigating a variety of problems including assessment of attitudes, opinions, conditions and procedure. Descriptive study is concerned with relationships and practices that exist, beliefs and processes that are ongoing, effects that are being felt, or trends that are developing (Best, 1970). Descriptive data are usually collected through questionnaires, interviews and observations. The descriptive survey design was considered by the researcher as the most appropriate for analyzing the improvement or otherwise in the poverty levels of the rural dwellers before and after the introduction of microcredit interventions in the community.

The case study design was adopted in the study. This method is mostly used for intensive study of individual units. By adopting this method, a single entity or phenomenon is explored, bounded by time and activity (Shrestha, 2003). Based on the above, Sinapi Aba Savings Trust was chosen for an indepth study. A case study strategy is mostly used in exploratory and explanatory research (Saunder et al, 2007). Explanatory research requires personal contact, so questionnaires (both closed and open ended semi-structured) were administered and faceto-face interviews conducted to gather and systematically track the client's responses on the contribution of microfinance to their socio-economic well-being.

\section{Research Population}

A study population is that aggregation of elements from which the sample is actually selected (Earl, 2002). It is the aggregate or the totality of all members or units from which information could be obtained (Rubin and Babbie, 2001). According to David and Chava (1976) a population could be defined in terms of content, extent and time. Cooper and Sciendler (2001) define population as the total collection of elements about which we wish to make some inferences. Therefore a population for this study included all women beneficiaries of Sinapi Aba Trust

\section{Sampling Procedure}

The sample was made up of sixty respondents in small-scale businesses like Foodstuff sellers, Provision stores, Hairdressers, Seamstress, Cooked food sellers. 
In selecting the sample, the metropolis was divided into clusters. The clusters were randomly chosen. The cluster sampling was chosen because the population is very large and spread over a wide geographical area.

After the selected cluster, the sectors were stratified into five groups

i) Domestic traders in manufactured goods

ii) Foodstuff sellers

iii) Primary Producers

iv) Secondary/Agro producers

v) Skills Training - Seamstress/Dressmaking

According to the stratums, the sub-divisions were selected to form the second stage group units. Entrepreneurs within the selected groups were listed and samples of them were chosen.

\section{Data Type, Sources and Collection Primary Source}

This source was obtained through the use of interview, focus group discussions and questionnaire. The purpose of these techniques was to allow probing to ascertain the impact of the microcredit on poverty reduction in the study area. This also allowed open discussion, which enabled me obtain information about women income generating activities. The high rate of illiteracy among my respondents calls for use of the open ended and semi-structured interview guide. In short, both quantitative and qualitative methods of data collection were employed in order to gather the data. But the qualitative method was the main focus in the presentation and analysis process of the data collected.

\section{Secondary Sources}

Credit Policy and Manual (Sefa, 2000) of SINAPI ABA TRUST was selectively reviewed for information upon permission from the author. Other Micro Credit Schemes for Women entrepreneurs like Ghana. Association of Women Entrepreneurs Freedom From Hunger Ghana who could not be contacted through the questionnaires were sourced through their brochures and other publications especially from World Bank report on Financial Services for women Entrepreneurs in the informal sector in Ghana.

\section{Data Instrumentation}

This research study deals with human beings in a particular area, therefore the methods employed included, Interviews, Questionnaire, Observations anAnalytical Tools

To systematically search for meaning from the data (Hatch, 2002), the researchers employed both descriptive and inferential statistics in analysing both the secondary and primary data.The responses to the questionnaires and interviews were edited and coded by the use of tables; charts, graphs, frequencies and percentages were than derived. The researcher adopted this technique since it was simple, easy to understand, analyze and draw conclusions.

\section{Results and Discussion}

This section deals with the background of and findings of the study. It will analyze and interpret the data collected from the study. An aspect of it will deal with the data collected 
from women entrepreneurs and those in respect of data collected from Sinapi Aba Trust both of which are in respect of the research questions.

\section{Background Analysis}

The background contains the age, education, duration of business existence, sources of startup finance of business and levels of start-up capital of women entrepreneurs.

Figure 1: Age of Women Entrepreneurs

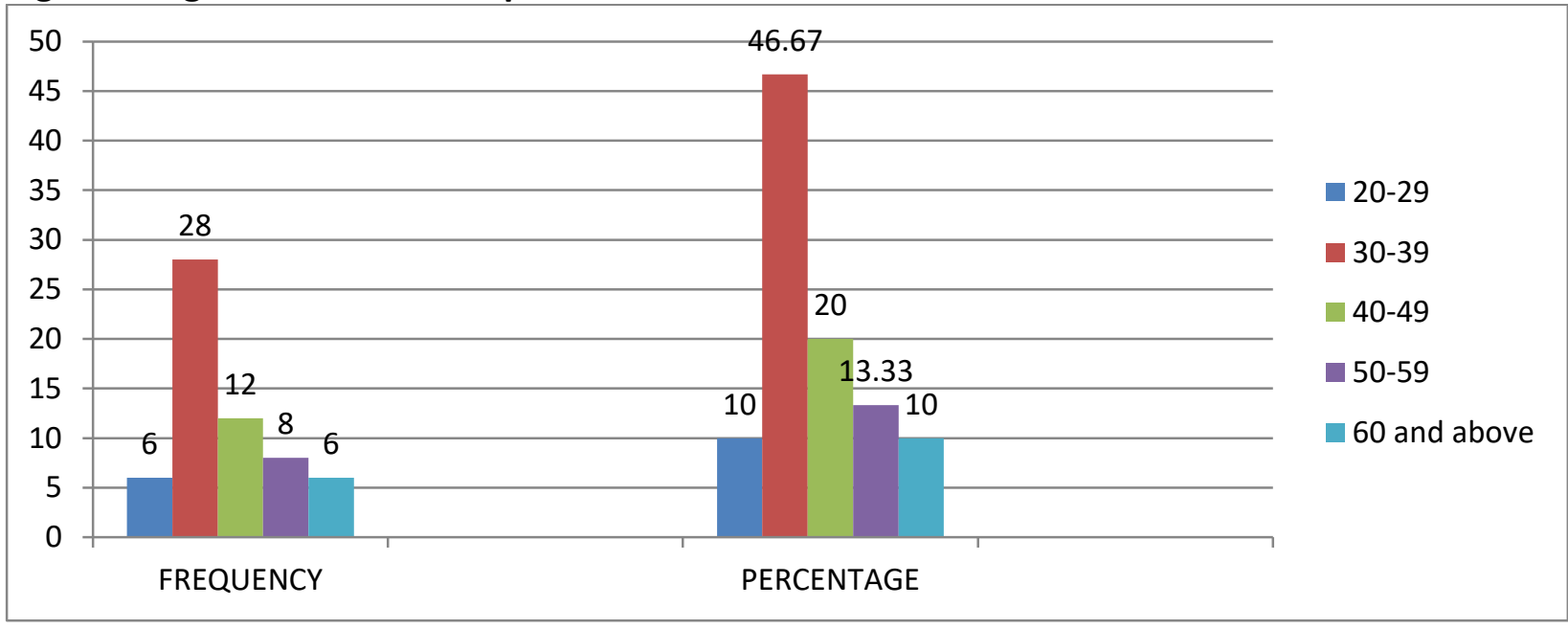

Source: Field Survey, 2002

From figure 1 above, entrepreneurs from 20-29 years were 10\%, 30-39 year 46.67\%, 40-49 $20 \%, 50-59$ years $13.33 \%$ and 60 years and above $10 \%$ with their corresponding frequencies.

Figure 2: Education of Women Entrepreneurs

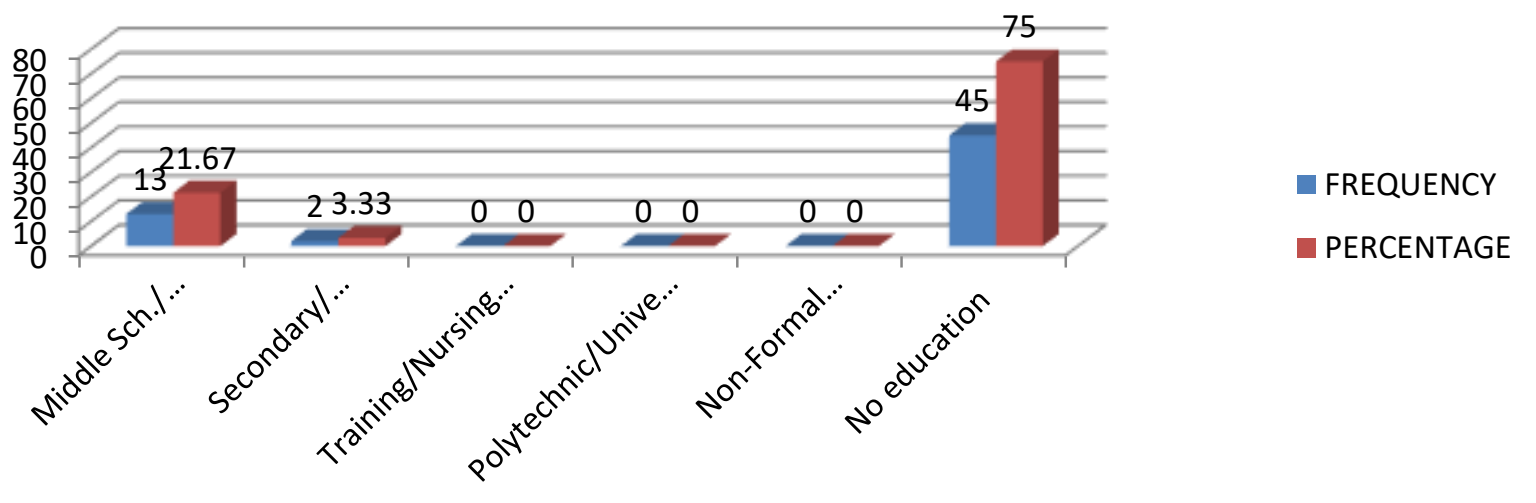

Source: Field Survey, 2002

From figure 2 above, $75 \%$ of the respondents had no formal education, $21.67 \%$ had completed Middle and Junior Secondary Schools, 3.33\% had completed Commercial and Vocational Schools with their corresponding frequencies. 
From figure 3 below, the respondents indicated the over $80 \%$ of their businesses had existed between 1 to 20 year. Businesses beyond 21 years are below 20\% with their corresponding frequencies.

Figure 3: Duration of Business Existence.

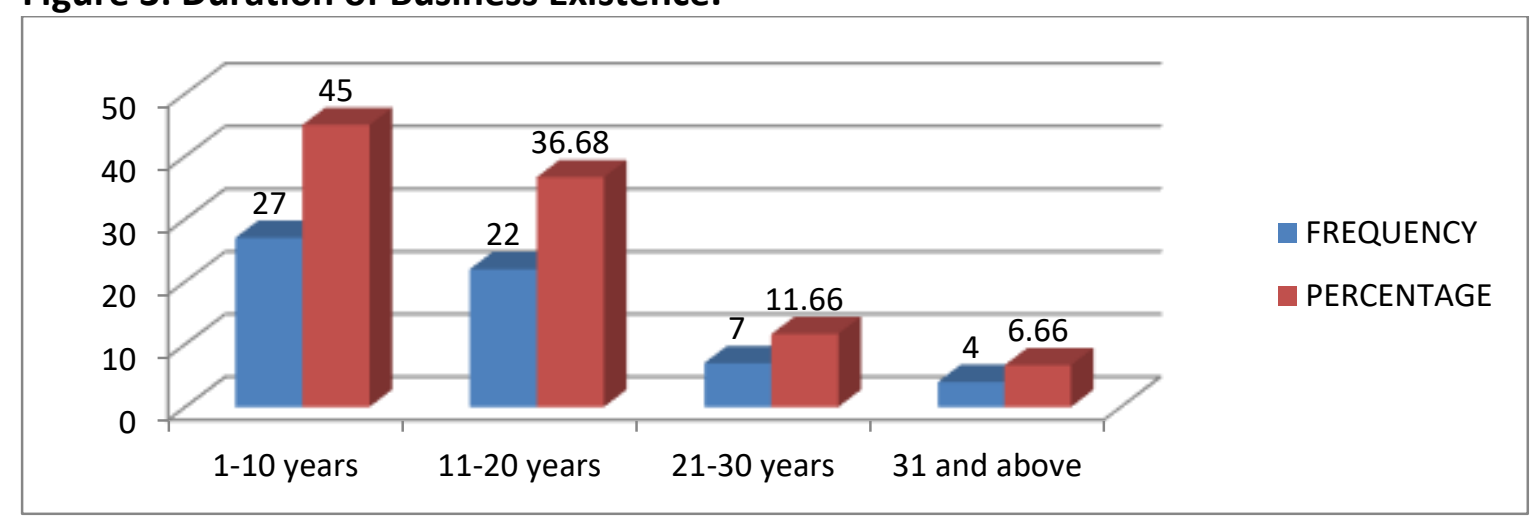

Source: Field Survey, 2002

Figure 4: Source (s) of Start-up Capital

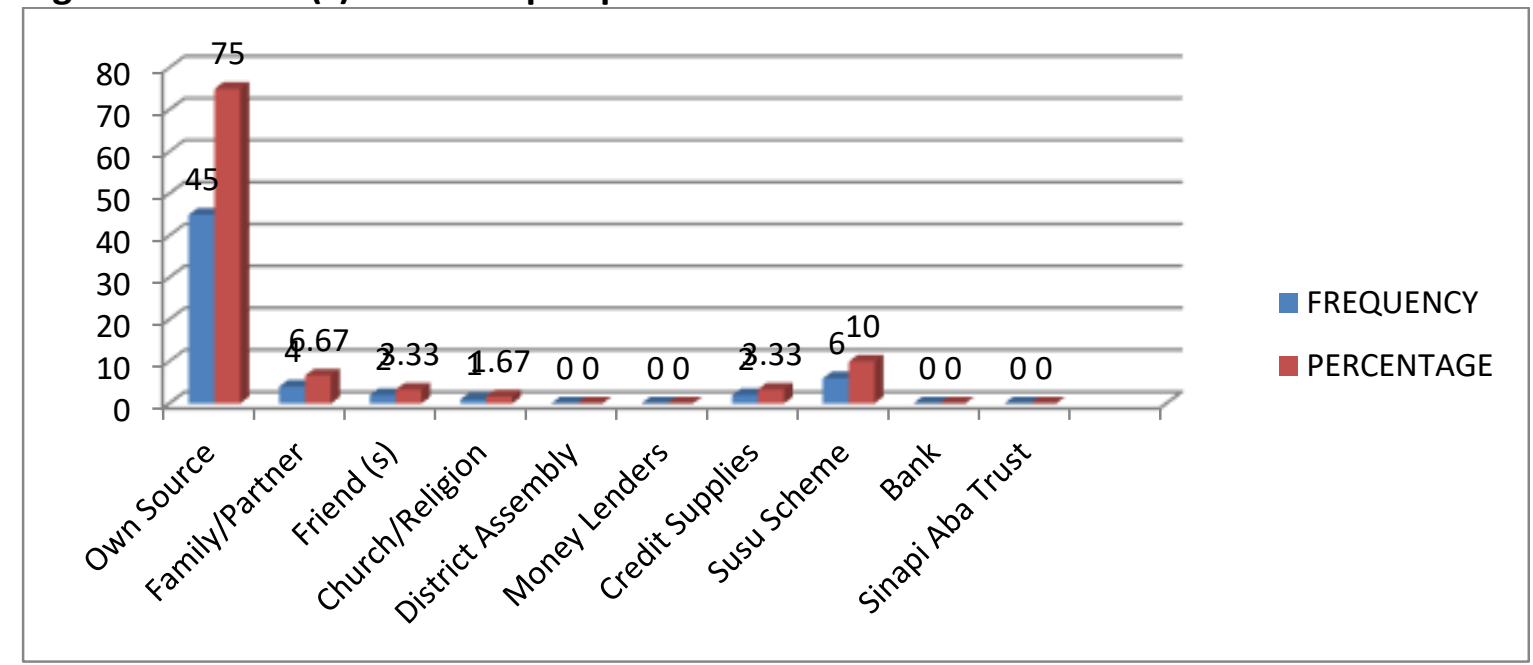

Source: A Field Survey (April, 2002)

From figure 4 above, $75 \%$ of respondents started business with their own source of capital, $6.67 \%$ constitute family member of partner, Susu Scheme contributes $8.33 \%$, while both friends and credit suppliers constitutes $3.33 \%$ each. Only $1.67 \%$ is from church and no respondent indicated as from government (District Assembly) with their corresponding frequencies. 
Figure 5: Sources of Current/Operating Capital

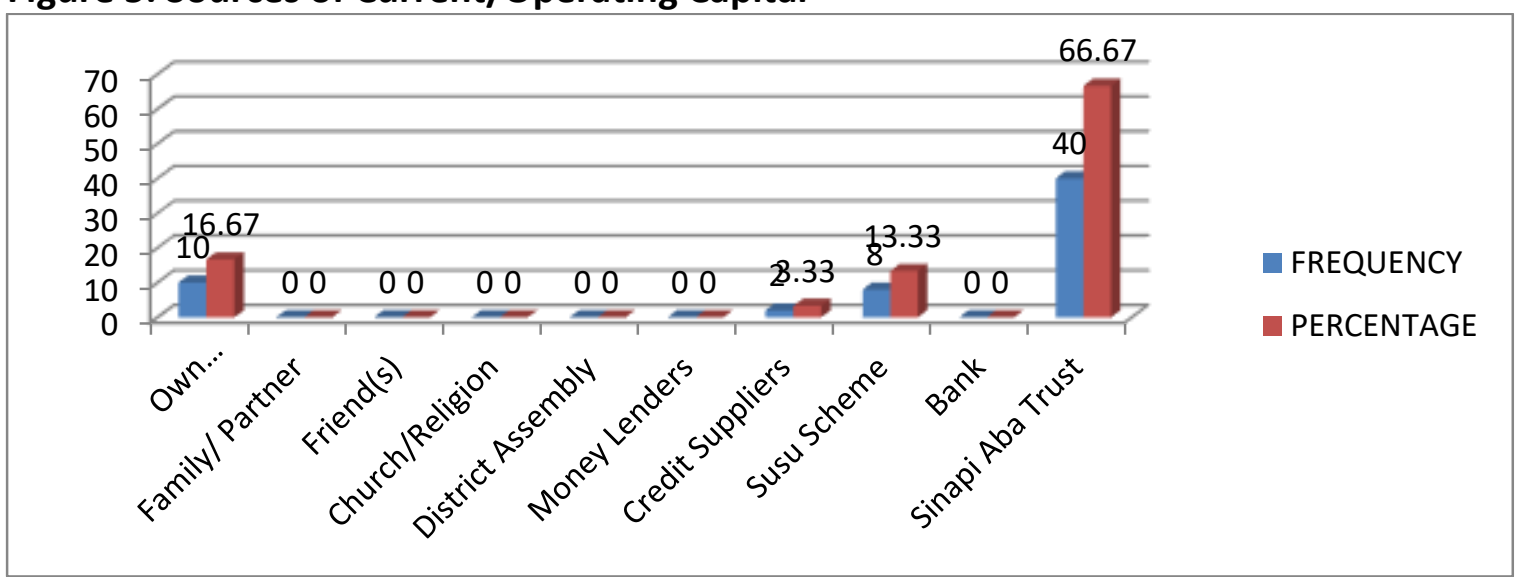

Source: Field Survey, 2002

From figure 5 above, $66.67 \%$ of respondents said their current source of operating capital is from SAT, $16.67 \%$ from own source/retained profit, $6.67 \%$ constitutes family member of partner, Susu Scheme contributes $13.33 \%$, while Credit Suppliers constitutes $3.33 \%$. no respondent indicated from church or from government (District Assembly) with his or her corresponding frequencies.

Mechanisms and measures are put in place to equip women entrepreneurs before the release of the micro Credit.

Figure 6: The impact of this orientation

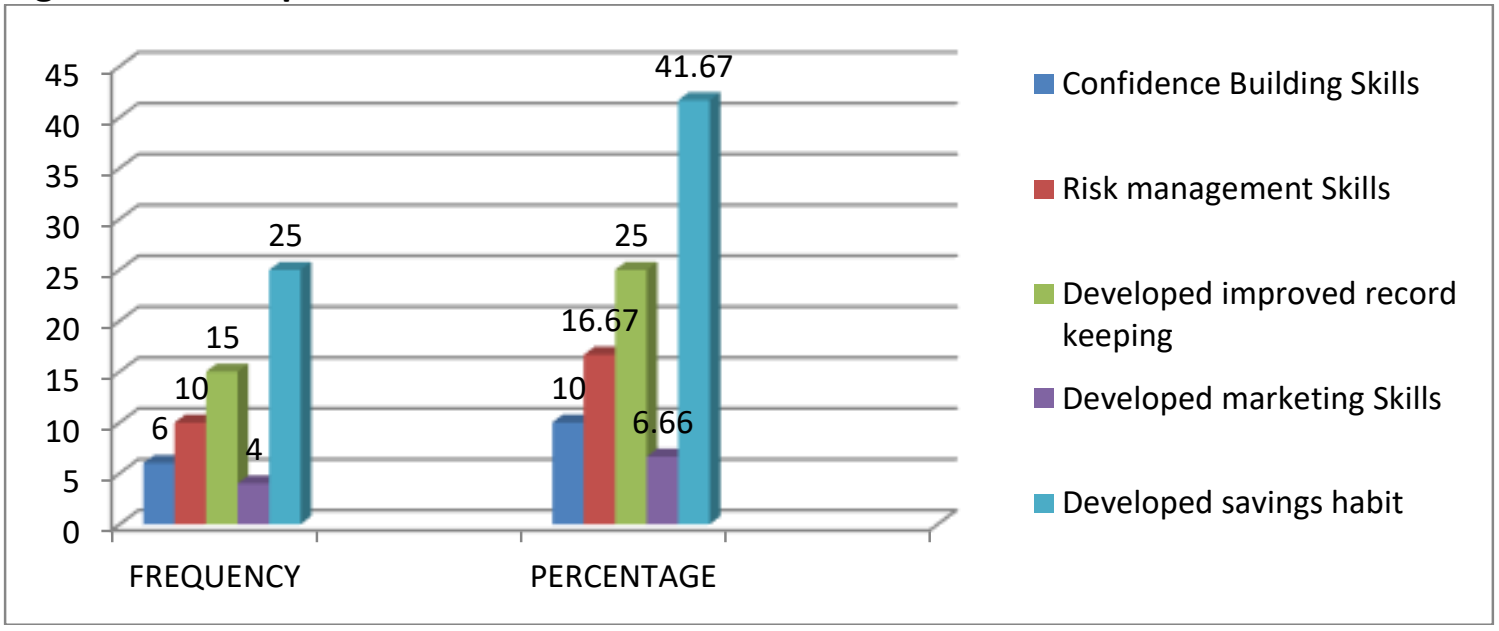

Source: Field Survey, 2002

From Figure 6 above, $41.67 \%$ indicated that the orientation and training has helped them to develop savings habit especially through susu scheme, $16.67 \%$ have developed business management skills, $10 \%$ have developed confidence building skills, $25 \%$ have developed personal and business record keeping and $6.66 \%$ have improved marketing skills with their corresponding frequencies. 
The Impact of Sinapi aba Trust on Women Entrepreneurs in the Kumasi Metropolis.

Figure 7: Number of women who have benefited up to date as at May 2002 and on yearly basis. 1997 as base year $=2,842$

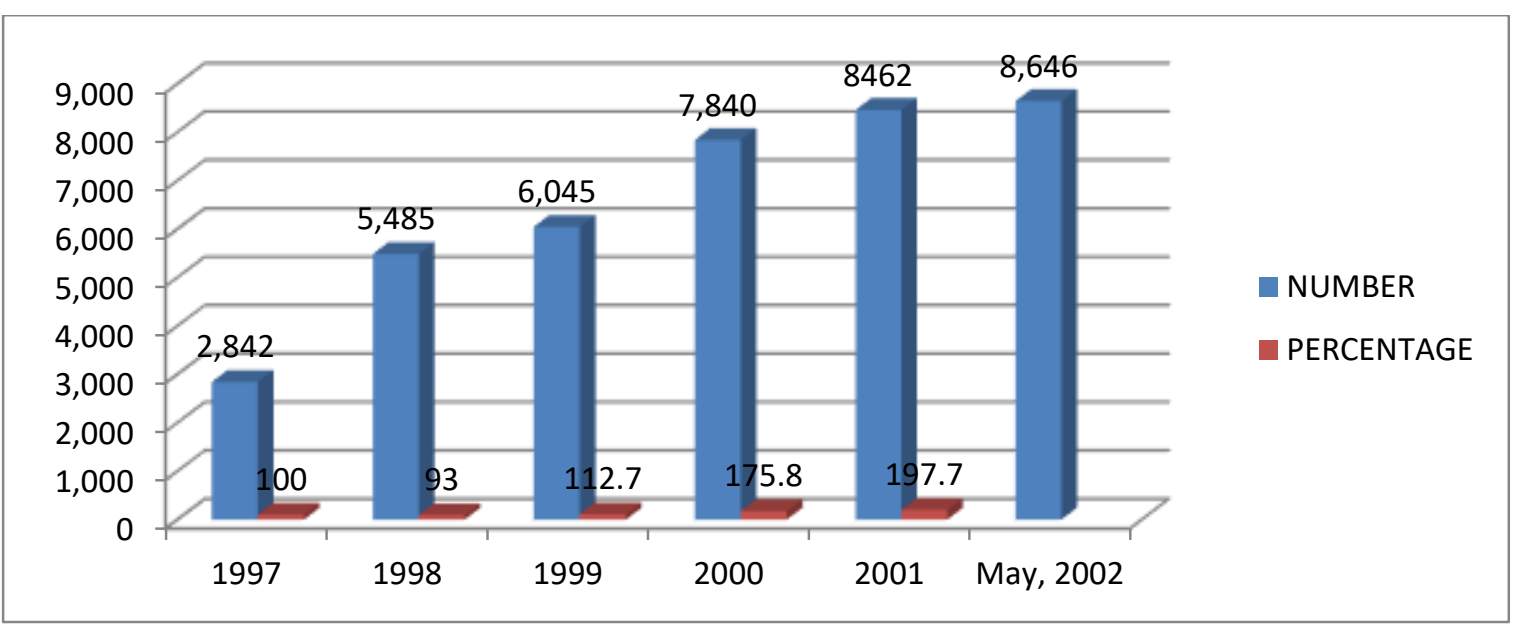

Source: Field Survey, 2002

From figure 7, the percentage increase is reflected in the fact that the scheme spreading in the metropolis over the period from 2,842 to 5,485 with a percentage increase of $93 \%$ in 1997. It increased by $112.7 \%$ in 1998 using 1997 as the base year. The trend had a consistent increase throughout up to May 2002 with a 204.2\% using 1997 as the base year

Figure 8: Selected businesses of women entrepreneurs that are supported.

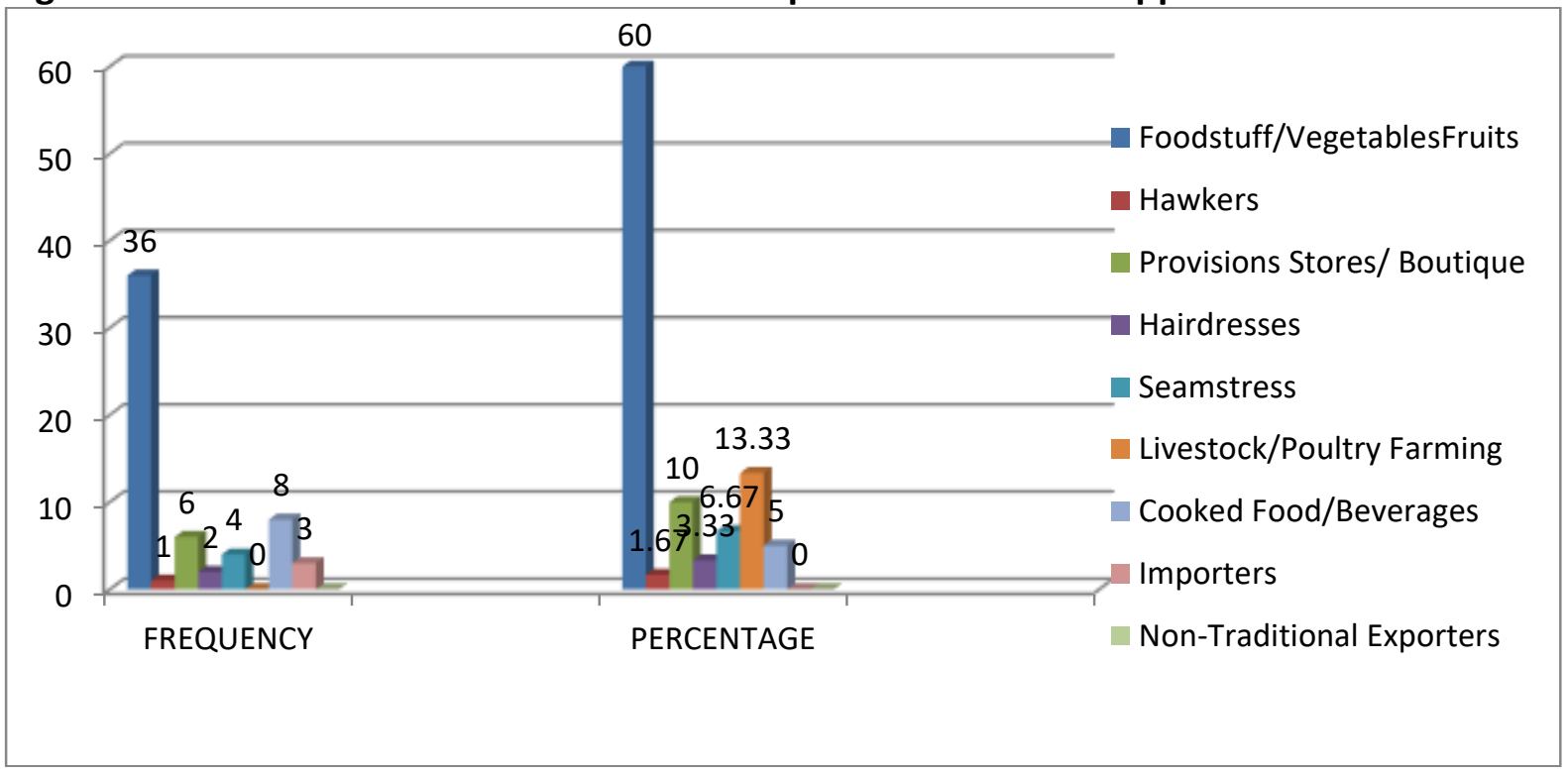

Source: Field Survey, 2002

From figure 8 above, $60 \%$ of respondents were foodstuff, vegetable and fruits sellers, $13.33 \%$ sell cooked food/beverage, $10 \%$ and importers of suiting materials/dresses were $5 \%$ with the corresponding frequencies. 
Based on the type of businesses shown in figure 8 above, foodstuff/vegetable/fruit sellers including provision stores and hawkers received initial amount ranging between $\$ 300,00$ to $\$ 1,000,000$, (1998-2002), hairdressers and seamstresses received between $\$ 500,000$ to $\$ 1,300,000$ (1998-200) and a similar amount for livestock and poultry farmers but could be given special concession up to $\$ 3,000,000$ and $\$ 6,000,000$. (Sefa, 2000).

\section{Standard Percentage Increase in Subsequent Credit Facility to Clients}

From the data available individual first time borrowers can receive up to $\$ 1,300,000$ and subsequent loans increases from $30 \%$ to $100 \%$ of the previous loan, or even more in special cases of remarkable performance. Group loans granted to urban starters receive up to $\$ 1,000,000$ and rural up to $\$ 800,000$.

Figure 9: Measuring the business growth and expansion of women entrepreneurs who are supported in Kumasi metropolis.

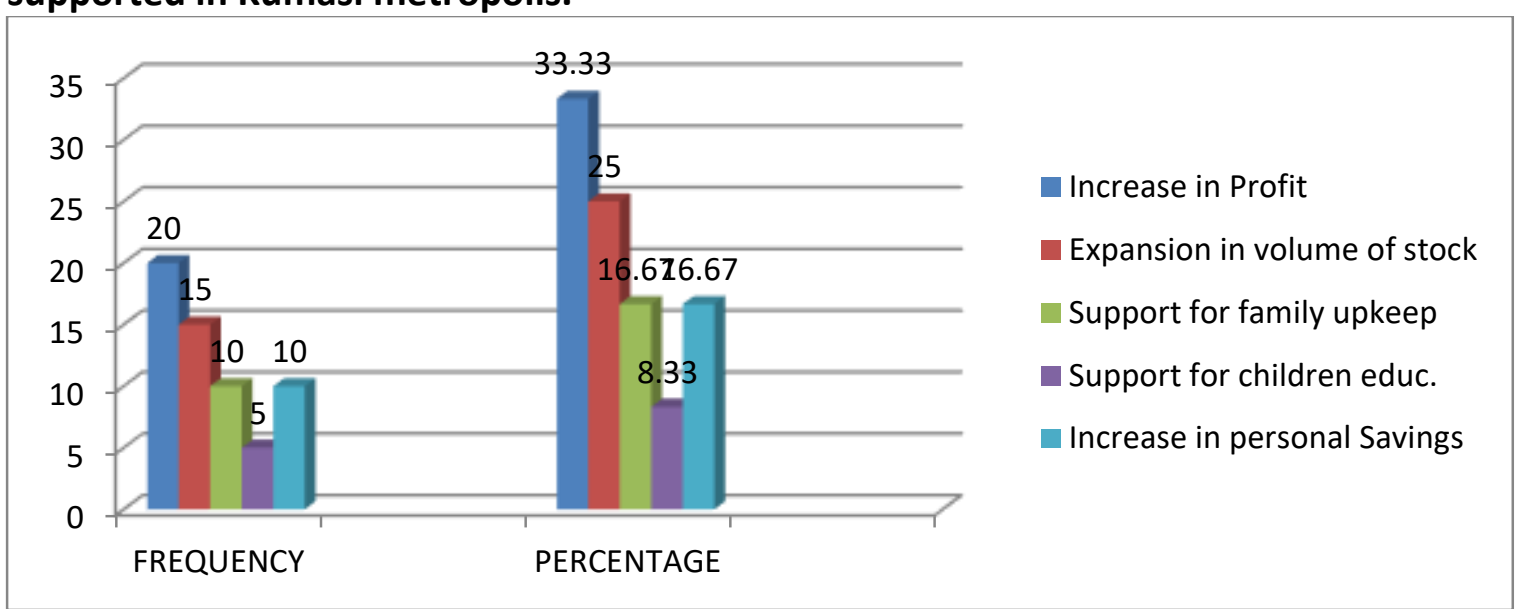

Source: Field Survey, 2002)

From figure 9 above, 33.33\% after receiving the micro credit had their profit increased, 25\% had expansion in volume of stock, $16.67 \%$ for both support for family upkeep and increase in personal savings and $8.33 \%$ experienced increase in support for children education.

\section{Beneficiaries Interest in Further Loans}

From figure 10 below, $66.67 \%$ of respondents indicated their interest in further loans as very high, $16.67 \%$ indicated their interest as high, $5 \%$ indicated as very low as well as those who were uncertain and $3.33 \%$ said it is very low to go for further loans with their corresponding frequencies. 
Figure 10: Beneficiaries interest in further loans

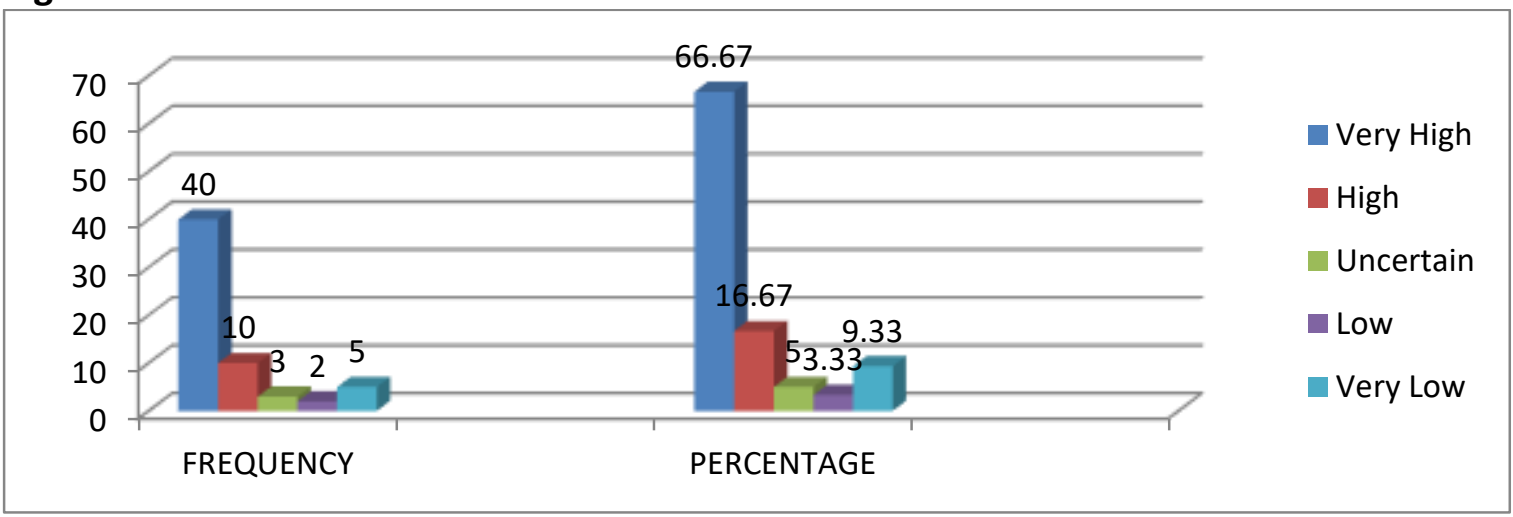

Source: Field Survey, 2002

Impact of Micro Credit on Beneficiaries

Figure 11: The Micro Credit has Impacted Positively on Beneficiaries

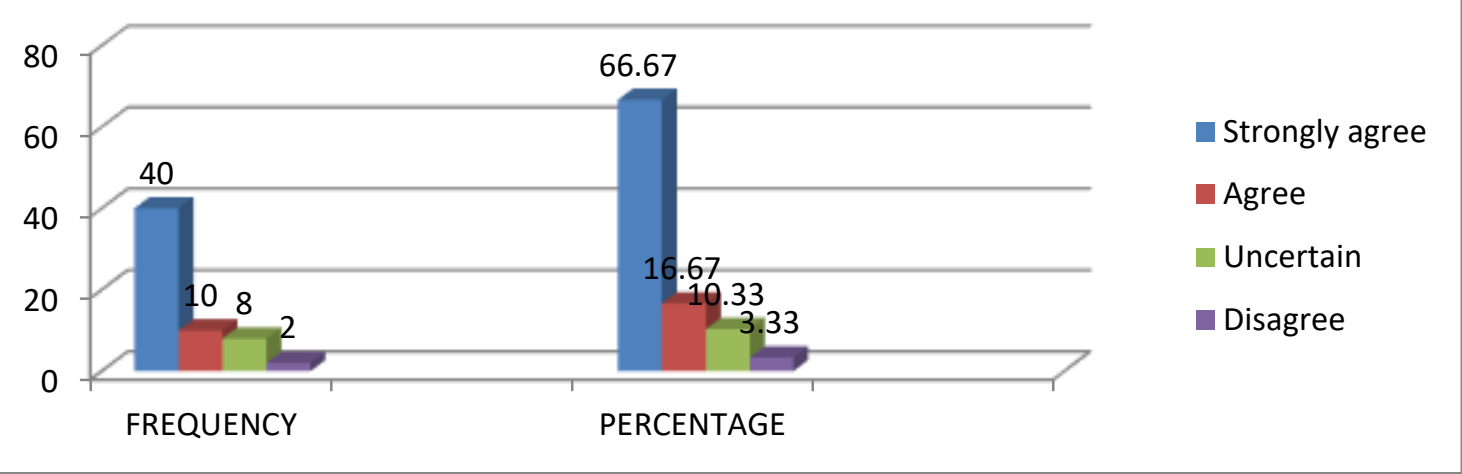

Source: Field Survey, 2002

From figure 11 above, $66.67 \%$ of respondents strongly agreed the micro credit has impacted positively on their businesses, $16.67 \%$ simply agreed, $13.33 \%$ were uncertain especially new recipients while $3.33 \%$ disagree.

\section{Interest Rates}

Figure 12: Are the interest rate acceptable?

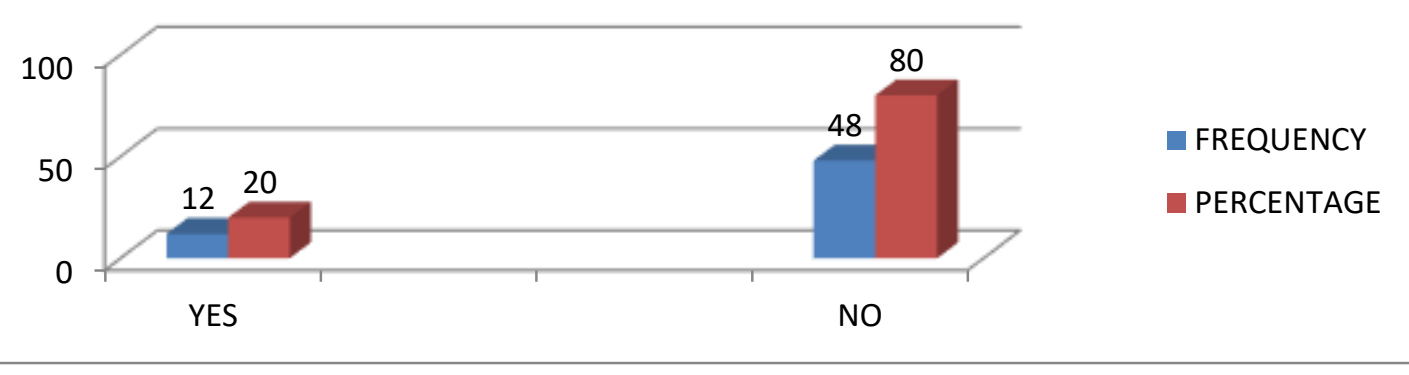

Source: Field Survey, 2002

Figure 11 shows that $80 \%$ of women beneficiaries were of the view that the interest rate is high, and $12 \%$ however, said if compared with some other sources of credit then it is not high. 


\section{Rating of Sinapi Aba Credit}

Figure 13: How do you rate Sinapi Aba Credit?

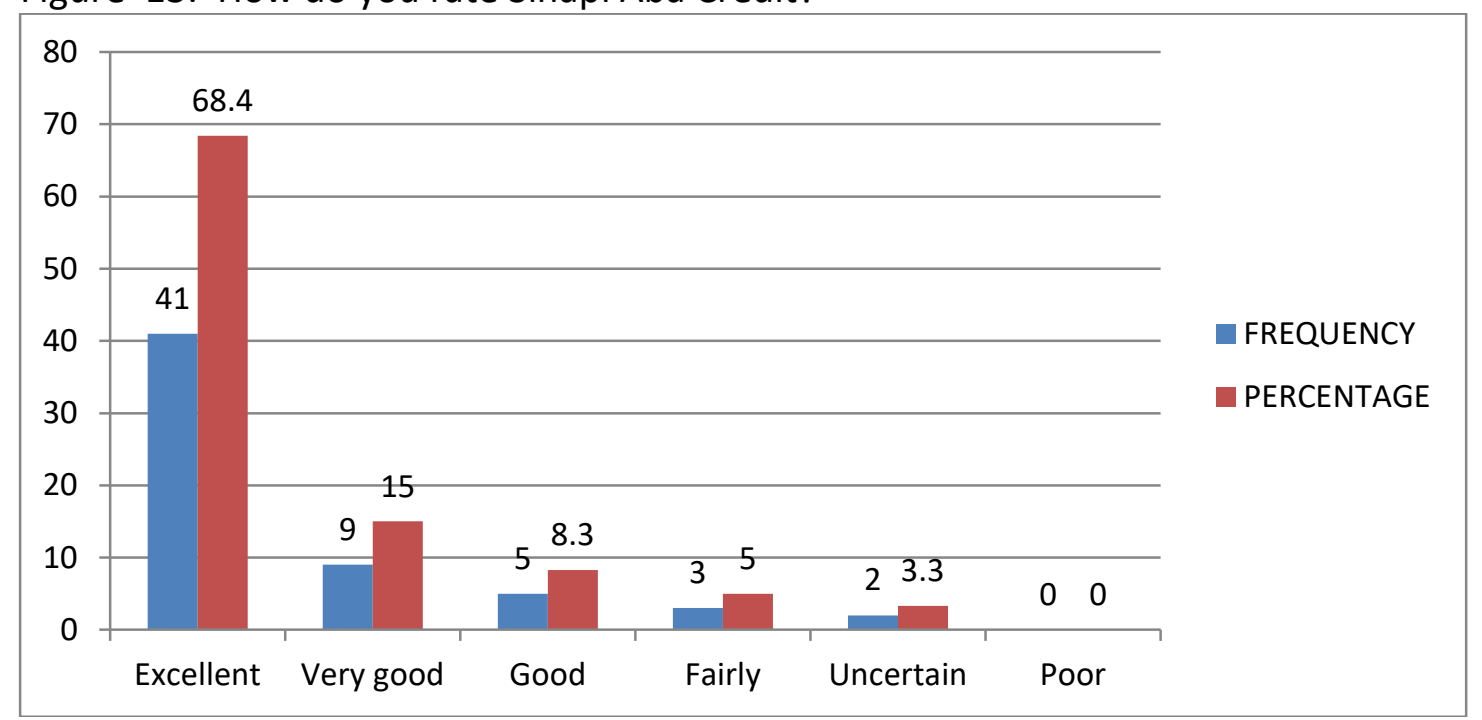

Source: Field Survey, 2002

From figure 13 above, $68.4 \%$ rated SAT credit as excellent, $15 \%$ as very good, $8.3 \%$ as good, $5 \%$ as fair and $3.3 \%$ said they were uncertain especially the new beneficiaries.

\section{Challenges Clients face in accessing credit}

Figure 14: Problems faced by small scale women entrepreneurs in the acquisition of credit from SINAPI ABA TRUST.

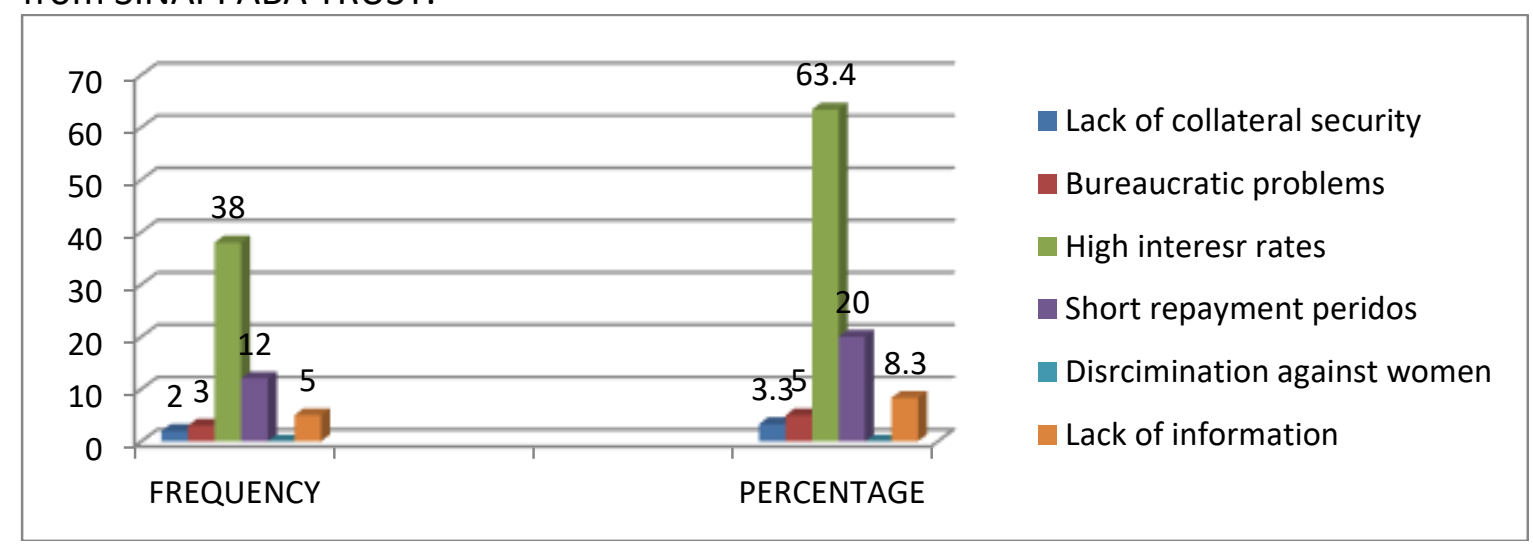

Source: Field Survey, 2002

From chart 14 above, $63.4 \%$ of respondents said the interest rate on credit is high, $20 \%$ said the payment period is high especially the group beneficiaries who pay weekly, $8.3 \%$ said there is lack of information on available sources of micro credit, $5 \%$ said the cumbersome process of securing credit is bit bureaucratic and only $3.3 \%$ said their problem is collateral/guarantors since group members who need higher credit need to get a guarantor but not fixed or landed property. 


\section{Loan Recovery Mechanisms}

Figure 15: Beneficiaries ability to pay back loans within schedule period

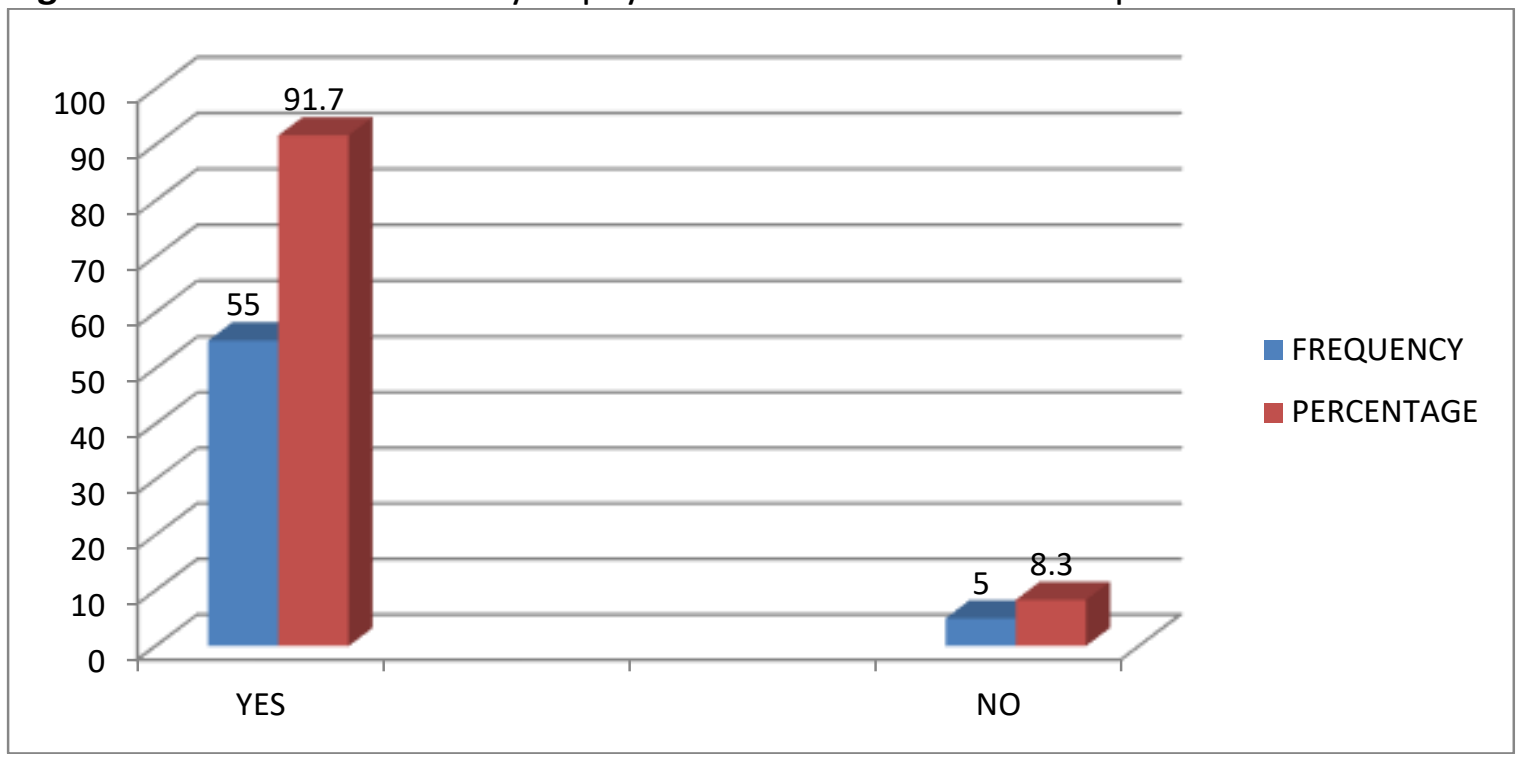

Source: Field Survey, 2002

From figure 15 above, approximately 92\% (91.7\%) of beneficiaries pay back loans within schedule periods and an $8.3 \%$ default that agrees with Sefa in charge of women entrepreneurs that over $85 \%$ pay back loans.

\section{Summary of Research Findings}

The research undertaken showed that non-banking financial institutions predominantly do micro credit financing to women entrepreneurs in the informal sector.

1) The study found out that $75 \%$ of women entrepreneurs in the informal sector had low level of formal education. The study further showed that most women entrepreneurs had insufficient start-up capital and even working capital. The cumbersome nature of the formal banking institutions had discouraged them to source its funding. Most of them had therefore depended on their own small savings and borrowing from family or friends. In the light of this, the study indicated that the innovative credit scheme by specialized micro finance institutions have boosted their desire to seek extra credit to expand their economic activities.

2) The study indicated that training for entrepreneurs as a prerequisite to access micro credit schemes have equipped them before and during the credit support period. Over $41 \%$ indicated the training had helped them to develop savings habit especially through Susu Group Scheme and about $17 \%$ have developed business management skills. Aryeetey (1996) said, "The principle of quick loan processing is characteristics of all informal sector loans". The study shows that group/trust bank innovative micro credit schemes provided an avenue to many applicants who might have not got guarantors to secure credit become accountable to each member in the group. Aryeetey (1996) said, "the scheme has a compulsory savings programme through loan (10\%) and loan repayment is done on weekly basis". 
3) The study indicated consistent increase in the beneficiary members and amount for loan renewal especially with the group loan scheme with an increase over $200 \%$. The study indicated that over $66 \%$ of respondents strongly agreed their interest for further loan from SINAPI ABA TRUST.

4) Furthermore, the study showed that over $60 \%$ of beneficiaries and respondents were engaged in foodstuff, vegetable and fruit sellers which are dominated by women in the informal sector. The study showed that women entrepreneurs have concentrated on limited scope of business activities based on traditional experience and home based activities for which capital requirements are also small.

5) The study showed that SINAPI ABA TRUST credit had had positive impact on their business and family income or education. $30 \%$ said it had increased their profit, $25 \%$ said it had increased their stock and sales and $17 \%$ said it had increased family upkeep and $8 \%$ experienced increase in support for their children education.

6) The study showed that the major challenge in accessing microcredit by women entrepreneurs was high interest rate of above $65 \% \%$ and again $20 \%$ said the short period of weekly repayment of loan instalment and $8 \%$ being lack of information. The study indicated that interest rates on micro credit had been high over the years due to such factors as high cost of loan processing and monitoring, high risk of default of repayment.

7) Furthermore, the study indicated that most women entrepreneurs in the informal sector lacked record keeping techniques with little or no formal record keeping accessing their cost and profit on business activities. This normally limits their prospects of obtaining sufficient working capital support. Khaleque \& Eusuf (2015), said women are relatively more credit constrained than men and they are discriminated in every stage. Therefore, credit constraint has a double effect on women led enterprises. However, training, education, and business experience can relax the credit constraint to a great extent.

"The performance of women entrepreneurs or the starting of new business is significantly influenced by entrepreneurial intention which is also influenced by personal and behavioral control". Dinc \& Budic, (2016).

\section{Recommendations}

After the thorough study, the following recommendations have been based on the research findings and conclusions made on micro credit support to women in the informal sector.

1. Microcredit institutions should include continuous training and education of entrepreneurs in the informal sector who have low educational background including skills and competencies in record keeping, risk management, financial education and marketing products;

2) There is the need for awareness creation among women entrepreneurs and networking among group members to enhance their ability to access credit and alternative credit sources at competitive interest rates. Women usually do not ask for loans and if they do the amount is comparatively small and they often do not know such credits exist or are available. This is 
because most of them basically lack access to resources such as credit, training and information.

3) The need to address high cost of capital and interest rates for small and micro enterprises of women to enable majority of them to repay their credit facilities. According to Jane, Agnes. \& Ondabu. (2014), The cost of credit accessibility refers to the amount of money the entrepreneurs pay in process of borrowing money from financial institutions. The key indicators of cost in this respect are processing fees, negotiation fees, interest rates, personal insurance, legal fees and travelling expenses that the entrepreneurs meet in the process of acquiring credit.

4) Financial institutions and microcredit institutions should instead of asking for collateral security which in most traditional societies preclude women must use other innovative ways such as cash flow, savings group history, mobile phone transaction history or a track record of business performance.

As cited by Touheda et al. (2017), in Perception of Women Entrepreneurs to accessing bank credit-In context of Sub-Saharan Africa, Asuming et al. (2018) suggest that policies related to financial inclusion should target lion share of the populations like women and youth. However, there is substantial disparity between men and women regarding access to as well as the use of finance (Ghosh \& Vinod, 2017).

Research on problems and challenges of the women entrepreneurs of developing countries reflects that unfavourable business environment, lack of support from credit providers, lack of skills developing training and market information, risk aversion, managerial competency and family responsibilities for children, are crucial determinants for women entrepreneurship development. (Bhuyan \& Abdullah, 2017, Shah \& Mustapha, 2014).

5. There is also the need for a change in the traditional (formal) education and child-rearing pattern, which must consider special entrepreneurial training for women and based study cycles. There is the need to review legislations, customs and traditions that restrict women's access to credit and property.

Zins \& Weill (2016), found that being a man, richer, more educated and older favour financial inclusion with a higher influence of education and income. Moreover, some socio-cultural factors impede the development of women entrepreneurs.

6. Women need greater access to a wider range of technical skill in accommodating their ongoing commitments. In this way technology centres should play a bigger role in identifying the technology needs of women's micro enterprises to increase their productivity of their businesses. They agrees with the assertion that even the poorest illiterate woman can improve the tiniest, most marginal business if she is given the king of assistance like credit, technical and training in the right way

7. The interest rate on the loans must be reasonably low to encourage them to repay with ease. There must be a scientific analysis in fixing periodic interest rates especially based on risk of default, cost of credit, inflation and bank of Ghana base rate. 
8. Monitoring of clients business activities should be strengthened to provide for proper guidance at their business premises and ensure effective recovery of loans. Banks and smallscale micro finance institutions need to employ female staff at decision-making levels and to orient all staff towards an appreciation of the value of women clients.

9. A state sponsored micro credit scheme such as MASLOC could collaborate with Rural Banks, Micro Credit Institutions and Women World Banking and other Micro Credit Scheme NonGovernmental Organizations with zero rated or up to a maximum of $10 \%$ interest rate for women entrepreneurs as this goes a long way to prevent high default rate,.

\section{Conclusions and Suggestions for Further Research}

1) Measures must be put in place to support women entrepreneurs who lack record keeping skills do not engage clerical staff to enable them gets reliable and accurate data to assess sales and profit to meets the requirements of obtaining higher loans.

2) The mechanisms put in place for loan recovery makes women entrepreneurs conscious of their responsibility to repay the loan. It also puts greater responsibility on the guarantors to ensure the client pays back the loan.

3) Women have a role subordinate to men, which reduces their own sense of self-confidence and assertiveness and produces an environment that is basically hostile to succeed in business. Celebioglu (2017), cited by Abdul K (2018) in Performance of Women Entrepreneurs: Does Access to Finance Really Matter ? States that studies show that gender inequality affects the women employment".

4) The study also agrees with the fact that women, despite their efforts in the past decade, remain the nation's single greatest untapped resources for small business growth and development. Mustapha S. (2019), Daily Graphic dated 10 ${ }^{\text {th }}$ September, 2019 page 13, said gender inequality still remains a major part of the global jobs challenges. Reducing gender gaps in the world of work can yield big development payoffs. These extend beyond themselves, including spillover effects on children; enhanced poverty reduction, catalyzing business productivity and broader social cohesion.

\section{Suggestions for Further Studies}

1. There is the need to replicate the study in rural and peri-urban settings of Ghana.

2. Comparative study of rural and urban women entrepreneurs in Ghana

3. Comparative study of male and female small-scale entrepreneurs in Ghana

\section{References}

1. Celebioglu, F. (2017), Women Empowerment in terms of Gender Inequality across the Province of Turkey, Eurasian Journal of Business and Economics, Vol. 10, NO. 19, pp. 61-80. http://doi.org/10.17015/eibe.2017.019.04

2. Dink, M. S. \& Budic, S. (2016), The Impact of Personal Attitude, Subjective Norm, and Perceived Behavioural Control on Entrepreneurial Intentions of Women, Eurosian Journal of Business and Economics, 9(17), 23-35. http://doi.org/10.17015/eibe.2016.017.02 
3. Johnson, S. (2013), From Microfinance to Inclusive Financial Markets: the challenges of Social Regulation. Oxford Development Studies, 41(Sup.1), 535-552.

4. Asuming, P.O, Osei-Agyei, L. G., \& Mohammed, J. I (2018), Financial Inclusion in SubSaharan Africa: Recent trends and determinants. Journal of Africa Business, 1-23. http://doi.org/10.1080./15228916.2018.1484209.

5. Ghosly, S. \& Vinod, D. (2017), What Constraints Financial Inclusion for Women? Evidence from Indian Microdata, World Development, 92,60-81, http://doi.org.10.1016), worlddev.2016,11.011

6. Shah, F. A. \& Mustapha, Z. (2014), Prospects of Women Entrepreneurship: A study of the Women Entrepreneurs of Kashmir Valley, Arth prabandh: A Journal of Economics and Management, 3(1), 103-116

7. Zins, A. \& Weill, L. (2016), The Determinants of Financial Inclusion in Africa. Review of Development Finance, 6(1), 46-57. http://doi.org/10.1016), jrdf, 2016.05.001

8. Jane A., Agnes N. \& Ondabu I. (2014), The cost of credit accessibility refers to the amount of money the entrepreneurs pay in process of borrowing money from financial institutions. The key indicators of cost in this respect are processing fees, negotiation fees, interest rates, personal insurance, legal fees and travelling expenses that the entrepreneurs meet in the process of acquiring credit. 